\title{
Effect of Wet Cupping on Serum Lipids Profile Levels of Hyperlipidemic Patients and Correlation with some Metal Ions
}

\author{
Layla A. Mustafa \\ Department of Chemistry \\ College of Science \\ University of Mosul
}

\author{
Rukzan M. Dawood \\ Department of Chemistry \\ College of Education for \\ Girls \\ University of Mosul
}

\author{
Osama M. Al-Sabaawy \\ Department of Biochemistry \\ Ninavah College for \\ Medicine \\ University of Mosul
}

(Received 8/1/2012; Accepted 12/3/2012)

\begin{abstract}
The present study was conducted to evaluate the effect of cupping therapy on serum lipid profile concentration and correlated to some trace elements $(\mathrm{Cu}, \mathrm{Zn}$, and $\mathrm{Mn})$. Thirty one men (35 to 55 years old), with hyperlipidemia and without antihyperlipidemic drug or high energy diet consumption for the duration of the study were subjected to cupping. The serum for total cholesterol, triglyceride, lipoprotein (HDL, LDL) and trace elements concentration was collected from brachial veins, and determined before cupping and then once a week for two weeks after cupping. Patients with hyperlipidemia who subjected for cupping show a significantly decrease $(\mathrm{p} \leq 0.05)$ in total cholesterol, LDL cholesterol, and LDL/HDL ratio by comparison before cupping, while there were no significant differences in serum HDL cholesterol and triglyceride concentrations. $\mathrm{Zn}$ concentration and $\mathrm{Cu} / \mathrm{Zn}$ ratio show a highly significant difference $(\mathrm{p}<0.001)$ after cupping and also showed a significant correlation with serum lipids profile after cupping, especially zinc metal.
\end{abstract}

Keywords: Cupping, Hyperlipidemia, Metal ions, Cholesterol.

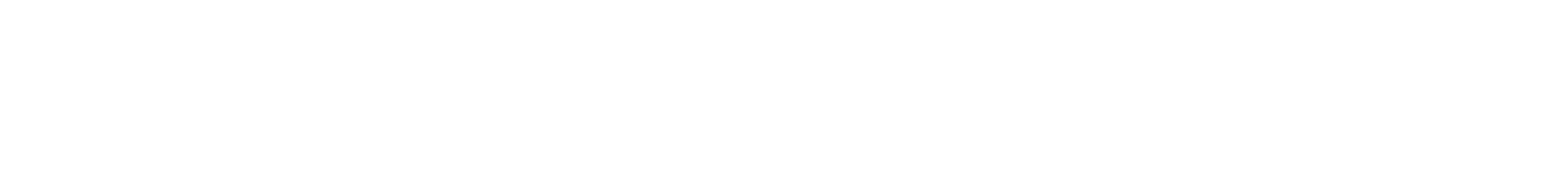

\section{|lld}

تضمن هذا البحث متابعة تأثثر الحجلمة على مستوى الدهون وعلاقتها ببعض الايونات المعنية (Cu) و

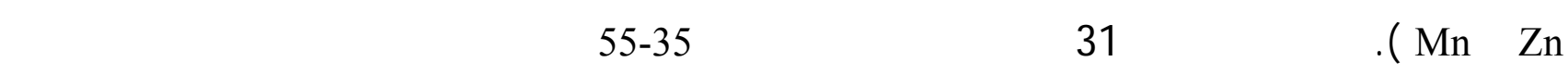

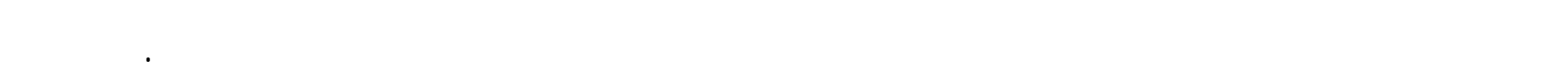
مستوى الكولسترول الكلي و الدهون الثلاثية والبروتينت الدهنية (HDL, LDL) والايونات المعنية في مصل 
المرض الخاضعين للحجلمة قل الحجامة و بعدها مرة ولحة في الأسبوع ولمدة لُٔبوعين. لُٔلهرت النتائج النخفاضا معنويا ( $\leq 0.05$ ) في مستوى الكولسترول الكلي والبروتينت الدهنية ولطئة الكثافة LDL وفي النسبة

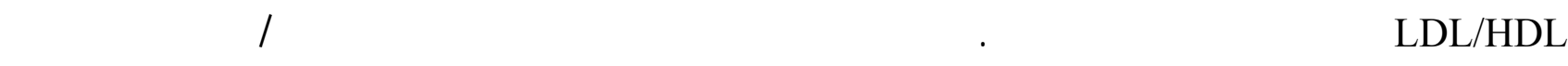

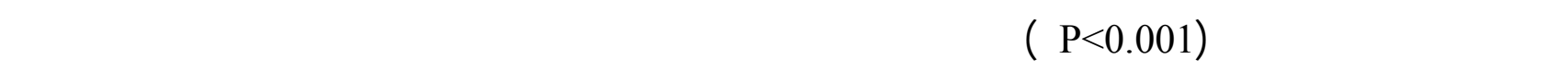
الايونات المعنية ومستوى الدهون قبل و بعد الحجلمة وخصوصا عنصر الخارصين.

الكاملت الدالة: حجلمة، ارتفاع الدهون، الايونكت المعنية، كولسترول.

\section{INTRODUCTION}

Cupping therapy is one of the oldest documented medical techniques (Koptchuk et al., 1997). It is an ancient method for treatment and cure of a broad range of conditions; blood diseases such as haemophilia, hypertention, rheumatic conditions, pain relief, inflammatory conditions, mental and physical relaxation (Kaleem et al., 2007), tension and migraine headache (Ahmadi et al., 2008) polycythemia, heamochromatosis (Wright et al., 2000), hyperlipidemia (Wei, 2005), menopause syndrome (Jiang et al., 2004), pain of the knee, liver diseases, renal and uretric colic and other diseases (Akhtar and Siddiqui, 2007). The aim of cupping is to extract blood that is believed to be harmful from the body which in turn rids the body of potential harm from symptoms leading to a reduction in well-being (Kaleem et al., 2007). The Arabic name for cupping therapy is Al-Hejamah which it has been part of middleeastern cultural practice for thousands of years with citations dating back to the time of Hippocrates (400BC) (Curtis, 2005). Sixty percent (60\%) of medical schools in the U.S.A have been teaching cupping as a part of complementary medicine (CM) (Eisenberg et al.,1998). It is also being practiced at Harvard medical school and Johns Hopkins medical center, two of the most prestigious medical centers in the world (Skaar, 2004). Cupping therapy can be divided into two broad categories; dry cupping and wet cupping. Dry cupping simply pulls the local underlying tissue up into the suctioning cup, whereas wet cupping uses the same technique, but adds scarification and bloodletting (Ahmadi et al., 2008). Hyperlipidemia which is divided into two subcategories; hypercholesterolemia which is responsible for atherosclerosis and ischemic heart disease, and hypertriglcridemia which responsible for pancreatitis. The effectiveness of repeated blood donation in lowering blood lipids has been studied. Prolonged repeated bloodletting is associated with a reduction in cardiovascular events (Niasari et al., 2007). Patients with hyperlipidemia who donated blood and received antihyperlipidemia drug had nearly a twofold reduction in serum total cholesterol, LDL cholesterol and triglyceride level in comparison with patients who were treated with antihyperlipidemia drug only (Niasari et al., 2007). Trace elements such as $\mathrm{Cu}, \mathrm{Zn}$ and $\mathrm{Mn}$ are essential nutrients for humans and are needed in very small amounts for many physiological functions, including immune, antioxidant function, growth and reproduction (Cunnane, 1988). Trace elements also affect many aspects of 
lipid metabolism through enzymes and have modulatory effects on the synthesis and metabolism of lipids (Koo and Williams, 1981). Therefore, the aim of the present study was conducted to investigate the effect of wet cupping on serum lipid profile in hyperlipidemic patients with correlation to trace elements. Significance of cupping is confirmed by the fact that our Prophet Mohammed (Sallallahu Alayhi Wasallam) advised Cupping (Hijama) in many prophetic traditions (Hadiths) and laid great emphasis in using it. In Hadith narrated by Ibn Umar reported that the Prophet Mohammed (Sallallahu Alayhi Wasallam) said "Cupping (hijama) on an empty stomach is best. In it are a cure and a blessing. It improves the intellect and the memory" [Saheeh sunan ibn Maajah (3487)].

\section{Subjects}

\section{MATERIALS AND METHODS}

Thirty one men (35-55 years old), were included in the present study; they were clinically and pathologically diagnosed as hyperlipidemic patients by a specialist doctors. The criteria of ATP III (Adult Treatment Panel III) were considered for enrollment in the study (Grundy et al., 2004). The patients whom subjected to wet cupping were fasted for 12-14hrs and without taking any of antihyperlipidemic drug or high energy diet consumption for the duration of the study. Wet - cupping was performed in one of private clinic for cupping in Mosul city by a specialized person. The hygienic procedure was conducted using consistent incisions ( 7 incisions with approximate depth of $2 \mathrm{~mm}$ and length of $1 \mathrm{~cm}$ ) and sucking for 3 minutes in the inter scapular area. On average, a total quantity of $50 \mathrm{ml}$ of blood was collected from each patient (Niasari et al., 2007).

\section{Samples}

Sera samples: 10 milliliters of venous blood obtained from each male before and after cupping and then once a week for two weeks after cupping. The blood allowed to stand at room temperature and then centrifuged at $3000 \mathrm{rpm}$ for $15 \mathrm{~min}$. serum separated and stored at $-20^{\circ} \mathrm{C}$ for subsequent analysis (Robby, 1980). Serum total cholesterol, HDL cholesterol and triglyceride levels were measured (Burtis and Ashwood, 1999) using kit enzymatic method from Biolabo Company (France). Indirect serum LDL cholesterol was calculated via the equation (friedwald formula): [Total cholesterol - (HDL+TG/2.2)] (Rifai and Warnick, 2006). Copper, zinc and manganese concentrations were measured using atomic absorption spectrophotometer (Shimadzo AA-670, Kyoto, Japan) (Tietz, 1999).

\section{Statistical Analysis}

The findings were expressed as the mean \pm standard deviation. The data analyzed with student's independent t- test. All statistical analyses were performed with the program statistical package for the social science (SPSS) for windows, version 10.0. A (p) value of $\leq$ 0.05 was accepted as statistically significant (Joaquim, 2007). 


\section{RESULTS AND DISCUSSION}

Serum concentrations of total cholesterol, HDL cholesterol, LDL cholesterol, triglyceride and LDL/HDL ratio are presented in Table 1. Patients with hyperlipidemic who subjected to cupping show a significant decrease $(\mathrm{p} \leq 0.05)$ in total cholesterol, LDL cholesterol and $\mathrm{LDL} / \mathrm{HDL}$ ratio $(5.04 \pm 0.67,3.62 \pm 0.69,3.44 \pm 0.94)(5.06 \pm 0.71,3.56 \pm 0.85,3.38 \pm 1.08) \mathrm{mmol} / \mathrm{L}$ in weeks 1 and 2 respectively by comparison before cupping $(5.41 \pm 0.68,4.03 \pm 0.7,3.99 \pm 1.08)$ $\mathrm{mmol} / \mathrm{L}$. While there were no significant changes in serum HDL cholesterol and triglyceride $(1.07 \pm 0.12,1.71 \pm 0.41)(1.08 \pm 0.11,1.69 \pm 0.32) \mathrm{mmol} / \mathrm{L}$ in weeks 1 and 2 respectively by comparison before Cupping $(1.04 \pm 0.11,1.69 \pm 0.42) \mathrm{mmol} / \mathrm{L}$.

Table 1: Concentrations of Lipid profile before Cupping and After Cupping

\begin{tabular}{|c|c|c|c|c|c|}
\hline \multirow{2}{*}{ Lipids profile } & \multirow{2}{*}{$\begin{array}{l}\text { Before } \\
\text { Cupping }\end{array}$} & \multicolumn{4}{|c|}{ After Cupping } \\
\hline & & Week 1 & $\begin{array}{c}\text { (p) } \\
\text { value }\end{array}$ & Week 2 & $\begin{array}{c}\text { (p) } \\
\text { value }\end{array}$ \\
\hline $\begin{array}{c}\text { Total } \\
\text { cholesterol }(\mathrm{mmol} / \mathrm{L})\end{array}$ & $5.41 \pm 0.68$ & $5.04 \pm 0.67$ & $0.036^{*}$ & $5.06 \pm 0.71$ & $0.05^{*}$ \\
\hline $\begin{array}{c}\mathrm{HDL} \\
\text { cholesterol(mmol/L) }\end{array}$ & $1.04 \pm 0.11$ & $1.07 \pm 0.12$ & 0.17 & $1.08 \pm 0.11$ & 0.1 \\
\hline $\begin{array}{c}\text { LDL } \\
\text { cholesterol }(\mathrm{mmol} / \mathrm{L})\end{array}$ & $4.03 \pm 0.7$ & $3.62 \pm 0.69$ & $0.023^{*}$ & $3.56 \pm 0.85$ & $0.022^{*}$ \\
\hline Triglyceride $(\mathrm{mmol} / \mathrm{L})$ & $1.69 \pm 0.42$ & $1.71 \pm 0.41$ & 0.827 & $1.69 \pm 0.32$ & 0.99 \\
\hline LDL/HDL ratio & $3.99 \pm 1.08$ & $3.44 \pm 0.94$ & $0.038^{*}$ & $3.38 \pm 1.08$ & $0.029^{*}$ \\
\hline
\end{tabular}

- Significant difference $\mathrm{P} \leq 0.05$

The result of the present study have shown a significant decrease $(\mathrm{p} \leq 0.05)$ in total cholesterol, LDL- cholesterol and LDL/HDL ratio in weeks 1 and 2 after cupping by comparison before cupping. While there were no significant changes in serum HDL cholesterol and triglyceride. Total cholesterol and LDL cholesterol concentrations in blood are highly correlated with the prevalence of coronary heart disease throughout the world (Keys et al., 1984). Observational studies of the incidence of disease have focused attention on the beneficial effects of lipid - lowering therapy in reducing both LDL cholesterol concentration and the frequency of clinical events (Anderson et al., 1987). The emphasis placed on lowering plasma LDL cholesterol concentration also reflects the increased risk of coronary heart disease in patients with heterozygous familial hypercholesterolemia, a disorder characterized by high plasma LDL cholesterol concentration and the early onset of coronary disease (Goldstein et al., 1995). The effect of Cupping on LDL- cholesterol that we observed in hyperlipidemic patients are consistent with the finding of previous study (Niasari et al., 2007) which shown that 
Cupping is an effective method in reducing LDL cholesterol and in LDL/HDL ratio, while not shown significant influence on each of total cholesterol, HDL cholesterol and triglyceride; therefore any change in the LDL/HDL ratio seem to be related to the reduction in LDL cholesterol. Lowering plasma cholesterol concentration reduce the availability of atherogenic lipoproteins and also, presumably, the accumulation of cholesterol in the intimae of arteries. Measures to lower cholesterol have become fundamental to the practice of preventive cardiology, and their use in both patients who already have coronary disease and healthy people has materially contributed to the $50 \%$ reduction in mortality from coronary heart disease in the united states (Sempos et al., 1988 ; Johnson et al.,1993).

Table 2: Concentrations of some trace elements before cupping and after cupping

\begin{tabular}{|c|c|c|c|c|c|}
\hline \multirow{2}{*}{ Trace Element } & \multirow{2}{*}{$\begin{array}{c}\text { Before } \\
\text { Cupping }\end{array}$} & \multicolumn{4}{|c|}{ After Cupping } \\
\cline { 3 - 6 } & $14.19 \pm 2.76$ & $16.58 \pm 1.39$ & $0.001^{*}$ & $16.10 \pm 3.63$ & $0.021^{*}$ \\
\hline $\mathrm{Zn}(\mu \mathrm{mol} / \mathrm{L})$ & $18.12 \pm 3.36$ & $17.65 \pm 3.00$ & 0.557 & $17.20 \pm 3.24$ & 0.273 \\
\hline $\mathrm{Cu}(\mu \mathrm{mol} / \mathrm{L})$ & $6.06 \pm 1.00$ & $5.93 \pm 1.01$ & 0.601 & $5.72 \pm 0.86$ & 0.144 \\
\hline $\mathrm{Mn}(\mu \mathrm{mol} / \mathrm{L})$ & $1.33 \pm 0.39$ & $1.07 \pm 0.20$ & $0.002^{*}$ & $1.11 \pm 0.32$ & $0.023^{*}$ \\
\hline $\mathrm{Cu} / \mathrm{Zn} \mathrm{ratio}$ & & & & & \\
\hline
\end{tabular}

* Significant difference $\mathrm{P} \leq 0.05$

Serum concentration of $\mathrm{Zn}, \mathrm{Cu}, \mathrm{Mn}$ and $\mathrm{Cu} / \mathrm{Zn}$ ratio are present in Table 2. Patients with hyperlipidemia who subjected to cupping show a significant increase $(p \leq 0.05)$ in $\mathrm{Zn}$ concentration $(16.58 \pm 1.39,16.10 \pm 3.63) \mu \mathrm{mol} / \mathrm{L}$ in week 1 and 2 respectively by comparison before cupping $(14.19 \pm 2.76) \mu \mathrm{mol} / \mathrm{L}$. The results showed a significant decrease $(\mathrm{p} \leq 0.05)$ in $\mathrm{Cu} / \mathrm{Zn}$ ratio $(1.07 \pm 0.20,1.11 \pm 0.32)$ in week 1 and 2 respectively by comparison before Cupping (1.33 \pm 0.39$)$. Non significant decrease in $\mathrm{Cu}$, $\mathrm{Mn}$ concentration (17.65 \pm 3.00 , $5.93 \pm 1.01) \mu \mathrm{mol} / \mathrm{L},(17.20 \pm 3.24,5.72 \pm 0.86) \mu \mathrm{mol} / \mathrm{L}$ in week 1 and 2 respectively by comparison before cupping $(18.12 \pm 3.36,6.06 \pm 1.00) \mu \mathrm{mol} / \mathrm{L}$. The results in Table 3,4 and 5 represent the correlations of serum trace elements concentrations of measured trace elements with total cholesterol, HDL- cholesterol, LDL- cholesterol, triglyceride and LDL/HDL ratio, showed a significant correlation between $\mathrm{Zn}$ concentration and lipid profile before and after cupping. 
Table 3 : Correlations of serum concentrations of $\mathrm{Zn}, \mathrm{Cu}$ and $\mathrm{Mn}$ with Lipid profile in serum of hyperlipidemic patients before cupping.

\begin{tabular}{|c|c|c|c|c|}
\hline & $\mathrm{Zn}(\boldsymbol{\mu m o l} / \mathbf{L})$ & $\mathrm{Cu}(\mu \mathrm{mol} / \mathrm{L})$ & $\operatorname{Mn}(\mu \mathrm{mol} / \mathrm{L})$ & $\mathrm{Cu} / \mathrm{Zn}$ ratio \\
\hline $\begin{array}{c}\text { Total } \\
\text { cholesterol }(\mathrm{mmol} / \mathrm{L})\end{array}$ & $\begin{array}{l}\mathrm{R}=-0.581 \\
\mathrm{P}=0.001^{*}\end{array}$ & $\begin{array}{l}\mathrm{R}=0.316 \\
\mathrm{P}=0.083\end{array}$ & $\begin{array}{l}\mathrm{R}=0.049 \\
\mathrm{P}=0.793\end{array}$ & $\begin{array}{l}\mathrm{R}=0.652 \\
\mathrm{P}<0.001^{*}\end{array}$ \\
\hline $\begin{array}{c}\text { HDL- } \\
\text { cholesterol(mmol/L) }\end{array}$ & $\begin{aligned} & \mathrm{R}=0.51 \\
& \mathrm{P}=0.003^{*}\end{aligned}$ & $\begin{aligned} R & =-0.333 \\
P & =0.067\end{aligned}$ & $\begin{aligned} R & =-0.049 \\
P & =0.794\end{aligned}$ & $\begin{array}{l}\mathrm{R}=-0.582 \\
\mathrm{P}=0.001^{*}\end{array}$ \\
\hline $\begin{array}{c}\text { LDL- } \\
\text { cholesterol }(\mathrm{mmol} / \mathrm{L})\end{array}$ & $\begin{array}{l}\mathrm{R}=-0.571 \\
\mathrm{P}=0.001^{*}\end{array}$ & $\begin{array}{l}\mathrm{R}=0.315 \\
\mathrm{P}=0.084\end{array}$ & $\begin{array}{l}\mathrm{R}=0.051 \\
\mathrm{P}=0.784\end{array}$ & $\begin{array}{l}\mathrm{R}=0.639 \\
\mathrm{P}<0.001^{*}\end{array}$ \\
\hline Triglyceride $(\mathrm{mmol} / \mathrm{L})$ & $\begin{array}{l}\mathrm{R}=-0.613 \\
\mathrm{P}<0.001^{*}\end{array}$ & $\begin{array}{l}\mathrm{R}=0.359 \\
\mathrm{P}=0.048^{*}\end{array}$ & $\begin{array}{l}\mathrm{R}=0.046 \\
\mathrm{P}=0.808\end{array}$ & $\begin{array}{l}\mathrm{R}=-0.711 \\
\mathrm{P}<0.001^{*}\end{array}$ \\
\hline LDL/HDL ratio & $\begin{array}{l}R=-0.566 \\
P=0.001^{*}\end{array}$ & $\begin{array}{l}\mathrm{R}=0.317 \\
\mathrm{P}=0.082\end{array}$ & $\begin{array}{l}\mathrm{R}=0.058 \\
\mathrm{P}=0.757\end{array}$ & $\begin{array}{l}R=-0.630 \\
P<0.001^{*}\end{array}$ \\
\hline
\end{tabular}

*Significant difference $\mathrm{P} \leq 0.05$

Table 4 : Correlations of serum concentrations of $\mathrm{Zn}, \mathrm{Cu}$ and $\mathrm{Mn}$ with Lipid profile in serum of hyperlipidemic patients after cupping (week 1).

\begin{tabular}{|c|c|c|c|c|}
\hline & $\mathrm{Zn}(\mu \mathrm{mol} / \mathrm{L})$ & $\mathrm{Cu}(\mu \mathrm{mol} / \mathrm{L})$ & $\operatorname{Mn}(\mu \mathrm{mol} / \mathrm{L})$ & $\mathrm{Cu} / \mathrm{Zn}$ ratio \\
\hline $\begin{array}{c}\text { Total } \\
\text { cholesterol }(\mathrm{mmol} / \mathrm{L})\end{array}$ & $\begin{array}{l}\mathrm{R}=-0.478 \\
\mathrm{P}=0.007^{*}\end{array}$ & $\begin{array}{l}\mathrm{R}=0.252 \\
\mathrm{P}=0.171\end{array}$ & $\begin{array}{c}\mathrm{R}=-0.149 \\
\mathrm{P}=0.422\end{array}$ & $\begin{array}{l}\mathrm{R}=0.542 \\
\mathrm{P}=0.002^{*}\end{array}$ \\
\hline $\begin{array}{c}\text { HDL- } \\
\text { cholesterol }(\mathrm{mmol} / \mathrm{L})\end{array}$ & $\begin{array}{l}\mathrm{R}=0.423 \\
\mathrm{P}=0.018^{*}\end{array}$ & $\begin{aligned} R & =-0.290 \\
P & =0.114\end{aligned}$ & $\begin{array}{l}\mathrm{R}=-0.136 \\
\mathrm{P}=0.467\end{array}$ & $\begin{array}{l}\mathrm{R}=-0.413 \\
\mathrm{P}=0.021^{*}\end{array}$ \\
\hline $\begin{array}{c}\text { LDL- } \\
\text { cholesterol }(\mathrm{mmol} / \mathrm{L})\end{array}$ & $\begin{aligned} \mathrm{R} & =-0.237 \\
\mathrm{P} & =0.198\end{aligned}$ & $\begin{array}{l}\mathrm{R}=0.256 \\
\mathrm{P}=0.165\end{array}$ & $\begin{array}{l}\mathrm{R}=0.150 \\
\mathrm{P}=0.412\end{array}$ & $\begin{array}{l}\mathrm{R}=0.313 \\
\mathrm{P}=0.087\end{array}$ \\
\hline Triglyceride $(\mathrm{mmol} / \mathrm{L})$ & $\begin{array}{l}\mathrm{R}=-0.495 \\
\mathrm{P}=0.005^{*}\end{array}$ & $\begin{array}{l}R=0.241 \\
P=0.192\end{array}$ & $\begin{array}{l}\mathrm{R}=0.173 \\
\mathrm{P}=0.351\end{array}$ & $\begin{array}{l}\mathrm{R}=0.412 \\
\mathrm{P}=0.021^{*}\end{array}$ \\
\hline LDL/HDL ratio & $\begin{array}{l}\mathrm{R}=-0.320 \\
\mathrm{P}=0.079\end{array}$ & $\begin{array}{l}\mathrm{R}=0.281 \\
\mathrm{P}=0.126\end{array}$ & $\begin{array}{l}\mathrm{R}=0.147 \\
\mathrm{P}=0.429\end{array}$ & $\begin{array}{l}\mathrm{R}=0.368 \\
\mathrm{P}=0.042^{*}\end{array}$ \\
\hline
\end{tabular}

*Significant difference $\mathrm{P} \leq 0.05$ 
Table 5 : Correlations of serum concentrations of $\mathrm{Zn}, \mathrm{Cu}$ and $\mathrm{Mn}$ with lipid profile in serum of hyperlipidemic patients after cupping (week 2 ).

\begin{tabular}{|c|c|c|c|c|}
\hline & $\mathrm{Zn}(\boldsymbol{\mu m o l} / \mathrm{L})$ & $\mathrm{Cu}(\mu \mathrm{mol} / \mathrm{L})$ & $\operatorname{Mn}(\mu \mathrm{mol} / \mathrm{L})$ & $\mathrm{Cu} / \mathrm{Zn}$ ratio \\
\hline $\begin{array}{c}\text { Total } \\
\text { cholesterol }(\mathrm{mmol} / \mathrm{L})\end{array}$ & $\begin{array}{l}\mathrm{R}=-0.470 \\
\mathrm{P}=0.008^{*}\end{array}$ & $\begin{array}{l}\mathrm{R}=0.349 \\
\mathrm{P}=0.054\end{array}$ & $\begin{array}{c}\mathrm{R}=-0.092 \\
\mathrm{P}=0.621\end{array}$ & $\begin{array}{l}\mathrm{R}=-0.092 \\
\mathrm{P}=0.621\end{array}$ \\
\hline $\begin{array}{c}\text { HDL- } \\
\text { cholesterol }(\mathrm{mmol} / \mathrm{L})\end{array}$ & $\begin{array}{l}\mathrm{R}=-0.448 \\
\mathrm{P}=0.011^{*}\end{array}$ & $\begin{aligned} \mathrm{R} & =-0.173 \\
\mathrm{P} & =0.352\end{aligned}$ & $\begin{array}{c}\mathrm{R}=-0.105 \\
\mathrm{P}=0.576\end{array}$ & $\begin{array}{l}\mathrm{R}=0.268 \\
\mathrm{P}=0.367\end{array}$ \\
\hline $\begin{array}{c}\text { LDL- } \\
\text { cholesterol(mmol/L) }\end{array}$ & $\begin{array}{l}\mathrm{R}=0.513 \\
\mathrm{P}=0.003^{*}\end{array}$ & $\begin{array}{l}\mathrm{R}=0.252 \\
\mathrm{P}=0.172\end{array}$ & $\begin{array}{c}\mathrm{R}=-0.155 \\
\mathrm{P}=0.404\end{array}$ & $\begin{aligned} \mathrm{R} & =-0.204 \\
\mathrm{P} & =0.272\end{aligned}$ \\
\hline Triglyceride $(\mathrm{mmol} / \mathrm{L})$ & $\begin{array}{l}\mathrm{R}=0.334 \\
\mathrm{P}<0.001^{*}\end{array}$ & $\begin{array}{l}\mathrm{R}=0.304 \\
\mathrm{P}=0.097\end{array}$ & $\begin{array}{l}\mathrm{R}=-0.055 \\
\mathrm{P}=0.767\end{array}$ & $\begin{array}{l}\mathrm{R}=-0.008 \\
\mathrm{P}=0.965\end{array}$ \\
\hline LDL/HDL ratio & $\begin{array}{l}\mathrm{R}=-0.526 \\
\mathrm{P}=0.002^{*}\end{array}$ & $\begin{array}{l}\mathrm{R}=0.241 \\
\mathrm{P}=0.192\end{array}$ & $\begin{array}{l}\mathrm{R}=-0.119 \\
\mathrm{P}=0.522\end{array}$ & $\begin{array}{c}\mathrm{R}=-0.206 \\
\mathrm{P}=0.267\end{array}$ \\
\hline
\end{tabular}

*Significant difference $\mathrm{P} \leq 0.05$

It is clear that deficiencies of some trace elements, such as $\mathrm{Cu}, \mathrm{Zn}$ and $\mathrm{Mn}$ can result in marked alterations in lipid and lipoprotein metabolism (Cunnane, 1988). To the best of our knowledge, there has been no previous research regarding the correlations of serum trace elements with lipids and lipoprotein in patients treated by Cupping. According to our results serum $\mathrm{Cu}$ had no significant correlation with lipid profile. Several studies reported an inverse relation between serum $\mathrm{Cu}$ and cholesterol in rats during $\mathrm{Cu}$ deficiency (Engle et al., 2000), while (Koo and Williams, 1981) found no significant correlation between the serum cu and cholesterol levels in non cu deficient rats. These findings suggest that the correlations between the serum $\mathrm{Cu}$ concentration and lipid levels in the physiological concentration may be different from the changes observed during $\mathrm{Cu}$ deficiency (Tajika and Nazifi, 2010), or due to that $\mathrm{Cu}$ form complexes with LDL (Lynch and Frei, 1995) and most of this binding apparently involves apolipoprotein B100, the major protein in LDL, and plays a role in lipid peroxidation (Wagner and Heinecke, 1997). According to our results, serum Zn concentration showed a significant increase and a positive correlation with HDL-cholesterol after Cupping, these results confirm the importance of $\mathrm{Zn}$ since it is essential for the function of more than 200 enzymes, and Zinc - containing enzymes are found in metabolic pathways involved in lipid metabolism (Cunnane, 1988). A Zinc deficiency induced hypercholesterolemia has been demonstrated in rat and dog models (Cunnane, 1988). Similar to our results (Suliburska et al., 2010) found a negative relationship between serum $\mathrm{Zn}$ and total cholesterol concentration in human, and (El- Hendy et al., 2001) showed that Zn deficiency increases serum cholesterol in a dose-dependent. Manganese is critical for lipid and lipoprotein metabolism, it has been 
demonstrated that Mn enhance cholesterol synthesis in the liver, However, our results showed a non significant negative correlation of the serum Mn with lipid profile.

\section{REFERENCES}

Akhtar, J.; Siddiqui, M.K. (2007). Utility of cupping therapy hijamat in unani medicine. Indian J. Traditional knowledge, 13 (1), 79-82.

Ahmadi, A.; Schwebel, D.C.; Rzaei, M. (2008). The Efficacy of Wet-Cupping in the treatment of tension and migraine headache. The Am. J. Chinese Medicine, 36(1), 37-44.

Anderson, K.M.; Castelli, W.P.; Levy, D. (1987). Cholesterol and mortality: 30 years of follow up from the Framingham study. JAMA, 257, 2176-80.

Burtis, C. A.; Ashwood, E.R. (1999). In: "Tietz Textbook of Clinical Chemistry and Molecular Diagnostics". 3rd edn. Saunders Co. Philadelphia, 857p.

Cunnane, S.C. (1988). Role of zinc in lipid and fatty acid metabolism and in membranes. Prog. Food Nutr Sci., 12, 151-188.

Curtis, N.J; (2005). Management of urinary tract infections: historical perspective and current strategies: part 1- before antibiotics. J. Urol., 173 (1), 21-26.

Eisenberg, D.M.; Davis, R.B.; Ettner, S.L. (1998). Trends in alternative medicine use in the United States. 1990-97. JAMA, 280, 1569-1575.

El-Hendy, H.A; Yousef, M. I.; Abo El-Naga, N.I. ( 2001). Effect of dietary zinc deficiency on hematological and biochemical parameters and concentration of zinc, copper and iron in growing rats. Toxicol., 167, 163-170.

Engle, T.E; Spears, J.W; Xi, L. (2000). Concentration in fishing steers dietary copper effects on lipid metabolism and circulating catecholamine. J. Am. Sci., 78, 2737-2744.

Goldstein, J.L.; Hobbs, H.H.; Brown, M.S. (1995). "Familial Hypercholesterolemia In: The Molecular and Metabolic Bases of Inherited Disease" (Seriver, C.R.; Beandet, A.L.; Sly, W.S.; Valle, D.). 7th vol. 2 New York: McGraw-Hill; pp.1981-2030.

Grundy, S.M.; Cleeman, J.I.; Merz, C.N.; Brewer, H.B.; Clark, L.T.; Hunninghake, D.B. (2004). Implications of recent clinical trials for the national cholesterol education program adult treatment panel iii guidelines. Circ. J., 110, 227-239.

Jiang, Zhen-Yal; He, Ling-nal; Li, chang-du (2004). Treatment of 48 cases of menopause syndrome by moving Cupping therapy along the meridians. J. Acupuncture and Tuina Sci., 2 (4), 37-38.

Joaquim, P. (2007). "Applied Statistics Using SPSS, Statistica, Matlab and R". 2nd edn., Springer Company USA., pp. 205-211, pp. 499-451.

Johnson, C.L.; Rifkind, B.M.; Sempos, C.T. (1993). Declining serum total cholesterol levels among US adults. The National Health and Nutrition Examination Surveys. JAMA, 269, 3002-8.

Kaleem, U.; Younis, A.; Wali , M. (2007). An investigation into the effect of Cupping therapy as a treatment for Anterior Knee pain and its potential role in health promotion. The Internet J. Alternative Med., 4(1).

Kaptchuk, T. J.; Dearlove, O.; Dearlove, J.; Seicol, N.H. (1997). Consequence of Cupping. $N$. Engl. J. Med., 336, 1109-1110. 
Keys, A.; Menotti, A.; Aravanis, C. (1984). The seven countries study: 2.289 deaths in 15 years. Prev Med., 13, 141-154.

Koo, I.; Williams, D. A. (1981). Relationship between the nutritional status of Zinc and cholesterol concentration of serum lipoprotein in adult male rats. Am. J. Clin. Nutr., 34, 2376-2381.

Lynch, S. M.; Frei, B. (1995). Reduction of copper, but not iron, by human low density lipoprotein (LDL)-implications for metal ion-dependent oxidative modification of LDL. J. Biol. Chem., 270, 5158-5163.

Niasari, M.; Kosari, F.; Ahmadi, A. (2007). The effect of wet cupping on serum lipid concentrations of clinically healthy young men: A randomized controlled trail. $J$. Altern. and Compl. Med., 13(1), 79-82.

Rifai, N.; Warnick, G.R. (2006). Lipids, lipoproteins, apolipoproteins, and other cardiovascular risk factors. In: "Tietz Textbook of Clinical Chemistry and Molecular Diagnostics" (Burtis, C. A.; Ashwood, E.R.; Bruns, D.E.). 4th edn. Saunders Co. Philadelphia, pp. 948.

Robby, B. (1980). The collection of blood specimens for biochemical analysis. Saudi Med. J., 1(3), 157-159.

Skaar, E. (2004). Why Bloodletting may actually worked. Science, 305, 1626-1628

Sempos, C.; Cooper, R.; Kovar, M.G.; McMillen, M. (1988). Divergence of the recent trends in coronary mortality for the four major race sex-groups in the united states. Am. J. Public Health., 78, 1422-7.

Suliburska, J.; Bogdanski, P.; Pupek-Musialik, D. (2010). Dietary intake and serum and hair concentration of mineral and their relationship with serum lipids and glucose levels in hypertensive and obese patients with insulin resistance. Biol. Trace Elem Res., 20, 195-197.

Tajik, J.; Nazifi, S. (2010). Correlation of serum lipids and lipoprotein with trace elements in water Buffalo. Veterinary Research Forum, 1 (2), 91-97.

Tietz, N.W.(1999). "Text Book OF Climical Chamistry". W.B. Saunders Company, Philadelphia.pp. 490-491, 1000-1025,1245-1250.

Wagner, P.; Heinecke, J.W. (1997). Copper ions promote peroxidation of low density lipoprotein lipid by binding to Histidine Residues of Apolipoprotein B100, but they are reduced at other sites on LDL. Arteriosclerosis, Thrombosis and Vascular Biol., 17, 3338-3346.

Wei, Z. (2005). Treatment of hyperlipidemia by acupuncture and cupping method on back-shu points. J. Acupuncture and Tuina Sci., 3(1), 14-15

Wright, S.M.; Finical, J. (2000). Beyond leeches: Therapeutic phlebotomy today. Am. J. Nurs., $100(55,56), 58-61$. 